\title{
Resting Discharge Patterns of Macular Primary Afferents in Otoconia-Deficient Mice
}

\author{
T. A. Jones ${ }^{1,2}$, S. M. Jones ${ }^{1}$, AND L. F. Hoffman ${ }^{2}$ \\ ${ }^{1}$ Communication Sciences and Disorders, School of Allied Health Sciences, East Carolina University, Health Sciences Building, \\ Rm 3310P, Greenville, NC 27858-4353, USA \\ ${ }^{2}$ Division of Head and Neck Surgery and Brain Research Institute, Geffen School of Medicine at UCLA, Los Angeles, CA 90095- \\ 1624, USA
}

Received: 5 November 2007; Accepted: 7 July 2008; Online publication: 27 July 2008

\begin{abstract}
Vestibular primary afferents in the normal mammal are spontaneously active. The consensus hypothesis states that such discharge patterns are independent of stimulation and depend instead on excitation by vestibular hair cells due to background release of synaptic neurotransmitter. In the case of otoconial sensory receptors, it is difficult to test the independence of resting discharge from natural tonic stimulation by gravity. We examined this question by studying discharge patterns of single vestibular primary afferent neurons in the absence of gravity stimulation using two mutant strains of mice that lack otoconia (OTO-; head tilt, het-Nox3, and tilted, tlt-Otop1). Our findings demonstrated that macular primary afferent neurons exhibit robust resting discharge activity in OTO- mice. Spike interval coefficient of variation $(\mathrm{CV}=\mathrm{SD} /$ mean spike interval $)$ values reflected both regular and irregular discharge patterns in OTOmice, and the range of values for rate-normalized $\mathrm{CV}$ was similar to mice and other mammals with intact otoconia although there were proportionately fewer irregular fibers. Mean discharge rates were slightly higher in otoconia-deficient strains even after accounting for proportionately fewer irregular fibers $[\mathrm{OTO}-=75.4 \pm 31.1(113)$ vs $\mathrm{OTO}+=68.1 \pm 28.5(143)$ in $\mathrm{sp} / \mathrm{s}]$. These results confirm the hypothesis that resting activity in macular primary afferents occurs in the
\end{abstract}

Correspondence to: T. A. Jones - Communication Sciences and Disorders, School of Allied Health Sciences · East Carolina University - Health Sciences Building, Rm 3310P, Greenville, NC 27858-4353, USA. Telephone: +1-252-7446088; fax: +1-252-7446109; email: jonesti@ecu.edu absence of ambient stimulation. The robust discharge rates are interesting in that they may reflect the presence of a functionally 'up-regulated' tonic excitatory process in the absence of natural sensory stimulation.

Keywords: sensory deprivation, spontaneous activity, resting activity, vestibular ganglion cells, primary afferents of the macula, vestibular macula, gravity receptors, vestibular spontaneous activity, discharge patterns

\section{INTRODUCTION}

Sensory information about ambient sound, head motion, and orientation in relation to gravity is provided to the brain by sensory organs located in the inner ear. This sensory information is first encoded in specialized mechanoreceptors known as hair cells. Hair cells in turn transfer sensory information to primary afferent neurons (ganglion cells) via chemical synaptic transmission. The information reaches the brain as action potentials conducted along ganglion cell processes. Ganglion cells of the auditory and vestibular nerve (i.e., eighth cranial nerve, VIIIn) as well as those of the lateral line in lower vertebrates are spontaneously active in mature animals. That is, in the absence of any sensory stimulation, ganglion cells exhibit robust discharge patterns with spike rates and probability features that depend in part on the particular sensory end organ they innervate (Fernandez et al. 1972; e.g., Goldberg and Fernandez 1971b; Jones and Jones 2000; Kiang 
1965). However, spontaneous discharge is not a general feature of all mature primary afferent neurons. It is virtually absent for example in primary afferents of dorsal root ganglia in the mature animal, although it is transiently present during ontogeny (Fitzgerald 1987; Fitzgerald and Fulton 1992).

The discharge of the eighth nerve sensory neurons in the absence of stimulation is thought to arise from a steady excitation due to background calciumdependent release of neurotransmitter from presynaptic hair cells (Adrian 1943; Annoni et al. 1984; Flock and Russel 1976; Furukawa et al. 1972; Furukawa and Ishii 1967; Harris and Flock 1967; Holt et al. 2006, 2007; Hudspeth 1986; Ishii et al. 1971; Katz 1969; Rossi et al. 1977; Schessel et al. 1991; Siegel 1992; Siegel and Dallos 1986; see recent review by Fuchs and Parsons 2006 regarding the details of synaptic release and physiology). The release of chemical neurotransmitter into the synapse by hair cells is thought to produce a steady background excitation of primary afferent dendrites and in turn lead to action potential discharge patterns. Thus, spontaneous activity in primary afferents of these systems can be considered to be autogenous in nature; that is, it arises from a process that begins within the hair cell and is independent of ambient stimulation. Evidence supporting this consensus hypothesis includes the observation that spontaneous discharge of neurons is reduced or eliminated by destroying hair cells (Kiang et al. 1976; Li and Correia 1998; Muller et al. 1997; Salvi et al. 1994, 1998) or by otherwise isolating neurons from hair cells in mature (Santos-Sacchi 1993) and neonatal animals (Risner and Holt 2006). Furthermore, uncoupling ambient stimuli fails to block spontaneous activity in some hair cell systems (e.g., plugging canals: Goldberg and Fernandez 1975 and Harris and Flock 1967; removing the cupula: Harris and Milne 1965), thus demonstrating an independence from external stimulation.

Sensory neurons innervating the cochlea or the semicircular canal end organs can be studied in the absence of experimental stimulation by controlling ambient sound and angular head motion. However, it is not possible to eliminate the stimulus action of gravity on macular organs for long periods of time in normal animals on Earth. Even when the head is motionless and in an 'Earth horizontal' position, there may be shearing forces acting on the underlying epithelium resulting in tonic stimulation, as it is virtually impossible to know the precise orientation of the utricle, for example, relative to the head and the ambient gravity vector. Thus, under normal conditions, it is not possible to entirely prevent stimulation of receptor end organs and thus, in the case of macular sensory elements, a tonic shearing displacement may act as a stimulus.
The discharge patterns of macular afferents in the absence of head motion (i.e., resting discharge) have been characterized in detail in mammals (Baird and Lewis 1986; Baird and Schuff 1994; Dickman et al. 1991; Fernandez et al. 1972, 1990; Fernandez and Goldberg 1976a; Goldberg et al. 1990b, a; Goldberg and Fernandez 1975; Loe et al. 1973; Tomko et al. 1981) and to some extent in birds (Anastasio et al. 1985; Jones and Jones 2000; Manley et al. 1991; Si et al. 1997). However, similar studies have not been completed in the absence of gravity loading of macular systems. It would be valuable to contrast resting discharge patterns of loaded versus unloaded macular receptors. This would provide a means to evaluate the role, if any, for static loading in the generation of resting mean discharge rates and characteristics. The discovery of mouse mutations that lack macular otoconia suggests an opportunity to study unloaded macular receptors and primary afferents in detail (Bergstrom et al. 1998; Hurle et al. 2001, 2003; Paffenholz et al. 2004).

In the absence of otoconia, the density gradients critical for stimulus action (e.g., by gravity or head translation) in maculae are absent. Natural stimulation therefore is not possible in these animals. Indeed, these mutant animals are unable to swim and orient properly in water and evidence no response to pulsed linear acceleration stimuli (Jones et al. 1999, 2004). Clearly these otoconia-deficient animals offer the potential for evaluating the effects of a chronically unloaded macula on vestibular circuits. However, as a preface to such investigation, it is essential to address in otoconia-deficient mice two fundamental questions: (1) Does the necessary synaptic apparatus exist to support spontaneous primary afferent discharge and (2) is spontaneous discharge actually present in macular afferents in these animals? Recent observations clearly show that the synaptic machinery, including ribbon synapses and vesicles, are abundant in the maculae of head tilt and tilted animals (Hoffman et al. 2006). We therefore hypothesize that macular primary afferents are spontaneously active in otoconia-deficient mice. The principal questions addressed in the current report were (1) are macular primary afferents spontaneously active in mice lacking otoconia, and if so, then (2) what is the nature of such resting discharge in comparison to mice having a normal complement of otoconia?

\section{METHODS}

Animals and surgical preparation

The care and use of animals in this study were approved by the Institutional Animal Care and Use 
Committees at East Carolina University (ECU) and the University of California at Los Angeles (UCLA) and conformed to all NIH guidelines. All animals included in this study were mice (Mus musculus) bred from stock obtained directly from The Jackson Laboratory (Bar Harbor, ME, USA) and maintained in closed colonies at ECU.

Unless otherwise stated, summary values reported here are expressed in the form $X \pm \mathrm{SD}(n)$ where $X$ is the mean, SD is the standard deviation, and $n$ is the sample size. The animals used in this investigation were weaned mice $[\sim 3$ to 13 weeks of age and on average were $43.2 \pm 12.3(87)$ days old].

Animals were randomly selected from first generation progeny of breeding crosses between confirmed homozygous "head tilt" mice [(CB57BL/6JEi-Nox $\left.3^{\text {het }}\right) /$ $\left(\right.$ CB57BL/6JEi-Nox $\left.3^{\text {het }}\right)$ ], abbreviated het $(-/-)$ (Bergstrom et al. 1998; Paffenholz et al. 2004; Sweet 1980); and heterozygous head tilt mice[(CB57BL/6J) / $\left(\mathrm{CB} 57 \mathrm{BL} / 6 \mathrm{JEi}-\right.$ Nox $\left.\left.3^{\text {het }}\right)\right]$, abbreviated het $\left.(+/-)\right]$ as well as confirmed homozygous tilted mice $[(\mathrm{C} 57 \mathrm{BL} / 6 \mathrm{~J}-$ Otop1tlt $) /(\mathrm{C} 57 \mathrm{BL} / 6 \mathrm{~J}-$ Otop1tlt $)$, abbreviated tlt $(-/-)$ (Hurle et al. 2001, 2003)]; and heterozygous tilted (C57BL/6J)/(C57BL/6J-Otoplttt), abbreviated tlt(+/-). The absence or presence of otoconia was confirmed postmortem in all animals by visual inspection of maculae under the dissecting microscope. In both strains, only homozygous mutants [het $(-/-)$ or $\operatorname{ttt}(-/-)]$ fail to develop otoconia, whereas all heterozygote animals [het $(+/-)$ or $(\operatorname{tlt}(+/-)]$ develop otoconia normally.

Animals demonstrating an absence of otoconia were assigned the otoconia-deficient phenotype $\left(\mathrm{OTO}^{-}\right)$and were designated as either a homozygous null het $[$ het $(-/-)]$ or $t l t[(\operatorname{tlt}(-/-)]$ genotype according to the source breeding cross. Animals demonstrating the presence of otoconia were assigned to the otoconia-present phenotype $(\mathrm{OTO}+)$ and designated as either a heterozygote het $[$ het $(+/-)]$ or a heterozygote $t l t[\mathrm{tlt}(+/-)]$ genotype according to the source breeding cross.

A swimming test (Jones et al. 1999; Lim et al. 1978; Ornitz et al. 1998) was performed on each animal immediately prior to experiments. Normal swimming behavior was represented by the animal's ability to orient in a head-up position and swim comfortably. Behaviors indicative of non-swimming animals included a marked failure to swim and orient properly as well as somersaulting and/or rolling movements in the water. Following each study, temporal bones were harvested, maculae dissected out, and examined for otoconia.

The animals were anesthetized with an intraperitoneal injection of anesthetic (ketamine/xylazine cocktail: ketamine, $18 \mathrm{mg} / \mathrm{ml}$; and xylazine, $2 \mathrm{mg} / \mathrm{ml}$; dose of a mixture of $0.07 \mathrm{ml} / 10 \mathrm{~g}$ body weight) and placed prone on a thermostatically controlled heating pad
(Fredrick-Haer, FHC 40-90-8c, DC temperature control module) that was attached to a turntable platform. The turntable was used to produce rotational stimuli for identifying semicircular canal afferents during our studies. The entire assembly was fixed on an air suspension table, which served to minimize vibration. The head of each animal was stabilized and held in position using skull screws embedded in plaster and was positioned initially nose-forward toward the axis of rotation with the interaural line lying approximately in the horizontal plane and nosepitched slightly downward to varying degrees. The head of each animal was placed approximately in the same spatial orientation during recordings in order to access the superior nerve with microelectrodes.

The distance between the table axis of rotation and the midline point of the interaural line of each animal was determined (mean $3.4 \pm 0.9 \mathrm{~cm}$ ). The animal was provided oxygen-enriched air to breathe via a polyethylene tube and mask. Respiratory and heart rates were monitored throughout the experimental procedures. A rectal probe was placed and temperature stabilized at $\sim 37.0 \pm 0.2^{\circ} \mathrm{C}$. Subcutaneous lactated Ringers solution was administered periodically $(\sim 0.5 \mathrm{ml} / \mathrm{h})$, and maintenance doses of anesthetic were administered as needed to maintain a deep surgical plane of anesthesia $(0.05 \mathrm{ml})$ throughout the experiment.

\section{Microsurgical procedures}

The left superior vestibular nerve was surgically accessed on the intracranial side of the temporal bone using a posterolateral approach. The left cerebellar hemisphere was exposed and the lateral lobes removed to expose the arcuate fossa and superior vestibular nerve at its entrance to the temporal bone. In the mouse, the superior branch of the vestibular nerve exits the temporal bone through a distinct meatus before joining other components of the eighth nerve as they project to the brainstem. The superior vestibular nerve and its internal meatus were exposed and clearly visualized in place under the microscope. For each electrode penetration, microelectrodes were advanced into the nerve under direct visual observation. Microelectrodes were glass-micropipettes-pulled using a Flaming/ Brown micropipette puller (Sutter Instrument Co. model P-97). The pipettes were filled with $0.5 \mathrm{M} \mathrm{KCL}$ in $0.05 \mathrm{M}$ Tris buffer ( $\mathrm{pH} 7.2-7.4)$ and were lowered to the nerve sheath using a micromanipulator. The tips were advanced into the nerve trunk using a Burleigh Inchworm stepper microdrive. A silver wire plated with silver chloride was placed in nearby superficial tissues and used as a reference electrode. Microelectrode impedance ranged from $\sim 10$ to 
$70 \mathrm{M} \Omega$ and was measured within the nerve using an electrometer (World Precision Instruments; model WPI 767).

\section{Electrophysiological recordings}

Many of the procedures used for electrophysiological recording have been described previously (see Jones and Jones 1995b, a; Jones et al. 2001, 2006; Jones and Jones 2000). Recordings of action potentials (spikes) were made from single vestibular primary afferent neurons located in the vestibular nerve. Records of "resting" activity (recorded in the absence of stimulation) as well as driven activity recorded during rotational stimulation were obtained. Neural activity was amplified, led to a window discriminator, a spike timer, and an analog tape recorder for storage and offline analysis. In addition, a calibrated Watson angular velocity sensor (model VSG-E469, sensitivity= $10^{\circ} / \mathrm{s} \mathrm{V}^{-1}$ ) was secured to the stimulus turntable and the output recorded on a separate channel of the analog tape. Signals recorded on tape were later digitized (16 bit conversion, 25,000 $\mathrm{Hz}$ sampling) and spike onset times determined and used to quantify action potential discharge characteristics.

The discharge of each neuron identified for study was characterized by determining the total recording time, total number of spikes, mean and instantaneous spike rate, mean spike interval, standard deviation of the spike interval (SDi), and interval coefficient of variation $(\mathrm{CV}=\mathrm{SDi} /$ mean spike interval). $\mathrm{CV}$ is a traditional metric used to characterize spontaneous discharge regularity (Fernandez et al. 1972; Goldberg and Fernandez 1971b). For vestibular neurons, CV is a function of spike discharge rate (Fernandez et al. 1972; Goldberg and Fernandez 1971b). These authors have argued that because CV for a given neuron can take on wide ranging values and because the curves of individual neurons tend not to intersect those of other neurons, cells may be uniquely ranked based on $\mathrm{CV}$ provided the comparison across neurons is made at the same discharge rate. For these reasons, procedures for normalizing $\mathrm{CV}$ for particular rates (generally designated $\mathrm{CV}^{*}$ ) have been developed and widely used (Baird et al. 1988; e.g., Baird and Lewis 1986; Goldberg et al. 1982, 1984, 1990b, a; Hullar et al. 2005; Lasker et al. 2008; Yang and Hullar 2007). Here, we normalized CV to a 15-ms interval based on the coefficients of Baird et al. (1988) for the chinchilla and on those of Lasker et al. (2008)for the mouse. The normalized CVs calculated using these coefficients were designated $\mathrm{CVC}^{*}$ and $\mathrm{CVm} *$, respectively.

All cells studied were recorded within approximately $2 \mathrm{~h}$ of the initial microelectrode penetration of the nerve (time available prior to temporal bone harvest).
Cells evidencing non-stationary discharge behaviors during recordings (e.g., evidencing injury discharge features such as fluctuating spike rates, CV, or spike amplitudes) were discarded.

Determining the response to stimulation

Typically, a recording of resting discharge activity was made for 40 to $60 \mathrm{~s}$ for each neuron. Subsequently, a series of auditory (complex sound transients) and vestibular stimuli were presented. No cell responded to auditory stimulation. Vestibular stimuli were rotations produced by sinusoidal movement of the turntable in the horizontal plane (sinusoid rotation: peak angular velocity ranging from $4^{\circ} / \mathrm{s}$ to $14^{\circ} / \mathrm{s}$ at frequencies from 0.5 to $1.5 \mathrm{~Hz}$ and peak angular acceleration ranging from approximately $13^{\circ} / \mathrm{s}^{2}$ to $132^{\circ} / \mathrm{s}^{2}$ ). These stimulus maneuvers were used to identify the presence of a response rather than to characterize the exact nature or sensitivity of the response discharge.

To examine records for responses to stimulation, spike discharge rate and angular velocity were plotted as a function of time. The graphs were adjusted to maximize the appearance of discharge rate fluctuations about the mean discharge rate. Discharge fluctuations were evaluated as a function of angular velocity by computing the cross correlation (i.e., the period histogram) of spike discharge over the stimulus period [discharge probability (spike count) vs cycle fraction (phase)]. Cells evidencing no consistent activation phase between spike discharge and stimulus cycle were regarded as being unresponsive to stimuli. Cells demonstrating a discernable ampullary response to rotation (i.e., a single period of activation during the stimulus cycle) were otherwise excluded from the data summaries presented here.

Labeling neurons and their dendrites

In order to verify that our recording site provided access to macular primary afferents, we injected a tract-tracing label and visualized the projections of neurons within the peripheral vestibular epithelia. During the course of each experiment, the tip of one or more microelectrodes was filled with the fluorophore 5-(and-6)-tetramethylrhodamine biocytin (biocytin TMR, Invitrogen) and beveled to achieve an impedance of $\sim 3 \mathrm{M} \Omega$. The electrode was lowered to penetrate the nerve sheath of the superior vestibular nerve as usual. Upon isolating a discharging neuron, a single 1-s pulse of air pressure ( $\sim 40 \mathrm{psi})$ was applied to the electrode to express a small quantity of label. The electrode was withdrawn to a position above the nerve sheath where a second pressure pulse was applied to confirm (under the microscope) the 
appearance of label at the electrode tip. Over the following 1 to $3 \mathrm{~h}$, electrodes were filled with KCL (without label), and electrode penetrations were made to study discharge patterns as usual using our standard unbeveled microelectrodes. At the end of the experiment, the temporal bones were harvested, the bone overlying the utricle and saccule was removed, the membranous labyrinth incised, and fixative (chilled $4 \%$ paraformaldehyde) was infused into the endolymphatic and perilymphatic spaces. The free temporal bones were then placed in fixative in the refrigerator for $4 \mathrm{~h}$ and ultimately transferred to buffered saline. The tissues were refrigerated until dissected, examined for otoconia, and processed for fluorescence microscopy (UCLA) within 10 days of harvest. The extent and nature of dendritic labeling was characterized using three-dimensional fluorescence confocal imaging.

\section{Scanning electron microscopy}

Siblings of animals used in the present study were randomly sampled, temporal bones harvested, and end-organ surfaces prepared for scanning electron microscopy (SEM). Mice were anesthetized, decapitated, and the temporal bones were exposed from the ventral side. The bullae were removed, and the oval and round windows opened with a fine needle. Fixative, $4 \%$ paraformaldehyde and $2 \%$ glutaraldehyde in $0.1 \mathrm{M}$ phosphate buffer ( $\mathrm{pH} 7.4$ ), was gently infused. Temporal bones were then dissected, the cochlear bone was opened, and specimens were stored in fixative 1 to 3 days at $4^{\circ} \mathrm{C}$. Specimens were then dehydrated in a graded series of ethanol: 30,50 , 80 , and $95 \%$ for $1 \mathrm{~h}$ each with gentle agitation and stored in $100 \%$ ethanol overnight. End organs (utricle and saccule) were dissected in $100 \%$ ethanol, critical point dried (Bal-tec CPD 030), mounted on aluminum stubs, and sputter-coated (Anatech Hummer 6.6). Specimens were viewed with a FEI Quanta 200 scanning electron microscope.

\section{Statistical analysis}

Data were analyzed using the general linear model for analysis of variance (ANOVA), linear regression, and the nonparametric chi-squared test $\left(\chi^{2}\right)$ available in SPSS 13 or 15. ANOVA was performed with and without covariates as noted in the result section. The threshold level of significance was $p=0.05$.

Traditional plots of $\mathrm{CV}$ versus mean inter-spike interval (ISI) were used to represent the distribution of CVs across discharge rates [i.e., ISI $=(1 /$ discharge rate) $\times 1,000$, in milliseconds]. Quantitative comparisons of these distributions were made by forming a $2 \times$ 2 grid that divided each CV-ISI plot into four regions as follows: region $1, \mathrm{CV} \leq 0.1$ and $\mathrm{ISI}<30 \mathrm{~ms}$; region 2 , $\mathrm{CV}>0.1$ and $\mathrm{ISI} \leq 30 \mathrm{~ms}$; region $3, \mathrm{CV}>0.1$ and $\mathrm{ISI}>$ $30 \mathrm{~ms}$; and region $4, \mathrm{CV} \leq 0.1$ and $\mathrm{ISI}>30 \mathrm{~ms}$. Counts of cells having CV-ISI pair values within each region, 1 through 4, determined the frequencies for each region, and these frequencies represented the distribution of CV-ISI pairs for each genotype or phenotype under consideration. The resulting frequencies were evaluated using the chi-squared statistic.

\section{RESULTS}

Typical examples of the utricular surfaces in the heterozygote and homozygote genotypes are shown in Figure 1. The abundance of otoconia for heterozygote animals $[\mathrm{het}(+/-)$ and $\mathrm{tlt}(+/-)]$ is illustrated in the example shown in Figure 1A. All animals demonstrating this normal otoconial phenotype (OTO+) oriented and swam normally in water. The absence of otoconia in otoconia-deficient animals is illustrated in Figure $1 \mathrm{~B}$ and C. Panels $\mathrm{B}$ and $\mathrm{C}$ show the otoconial membranes devoid of otoconia for the OTO- phenotype of homozygous tlt $(-/-)$ and het $(-/-)$ animals, respectively. All animals demonstrating the OTOphenotype failed to orient and swim normally in water.

The results of confocal imaging showed that labeled neurons of the superior vestibular nerve projected to the utricle, the sacculus, and the cristae of the superior and horizontal canals in all genotypes. Labeled terminal dendrites were distributed throughout the epithelium in the utricle and cristae, whereas labeled terminals were restricted to the epithelium of the short limb of the sacculus. A similar distribution of terminal dendrites has been reported for the superior nerve in other mammals including the squirrel monkey and chinchilla (e.g., Fernandez et al. 1972, 1988). Detailed studies of the vestibular neuroepithelia and terminal fields of afferents from animals used in the present study have been completed and are currently being evaluated (Hoffman et al. 2007a, b; Yao et al. 2007).

Two hundred sixty-six primary afferent neurons from the superior vestibular nerve were recorded in the present study. Resting discharge patterns were collected and analyzed from 256 of these cells (143 normal, OTO+; 113 otoconia-deficient, OTO-). Cells contributing to the resting discharge data were obtained from 86 mice (49 normal and 37 otoconiadeficient). The probability of isolating cells for study was essentially the same for each genotype and similar to other studies of mouse vestibular primary afferent neurons (Yang and Hullar 2007). On average, approximately three neurons were obtained from each animal regardless of phenotype [ratio of neurons to 

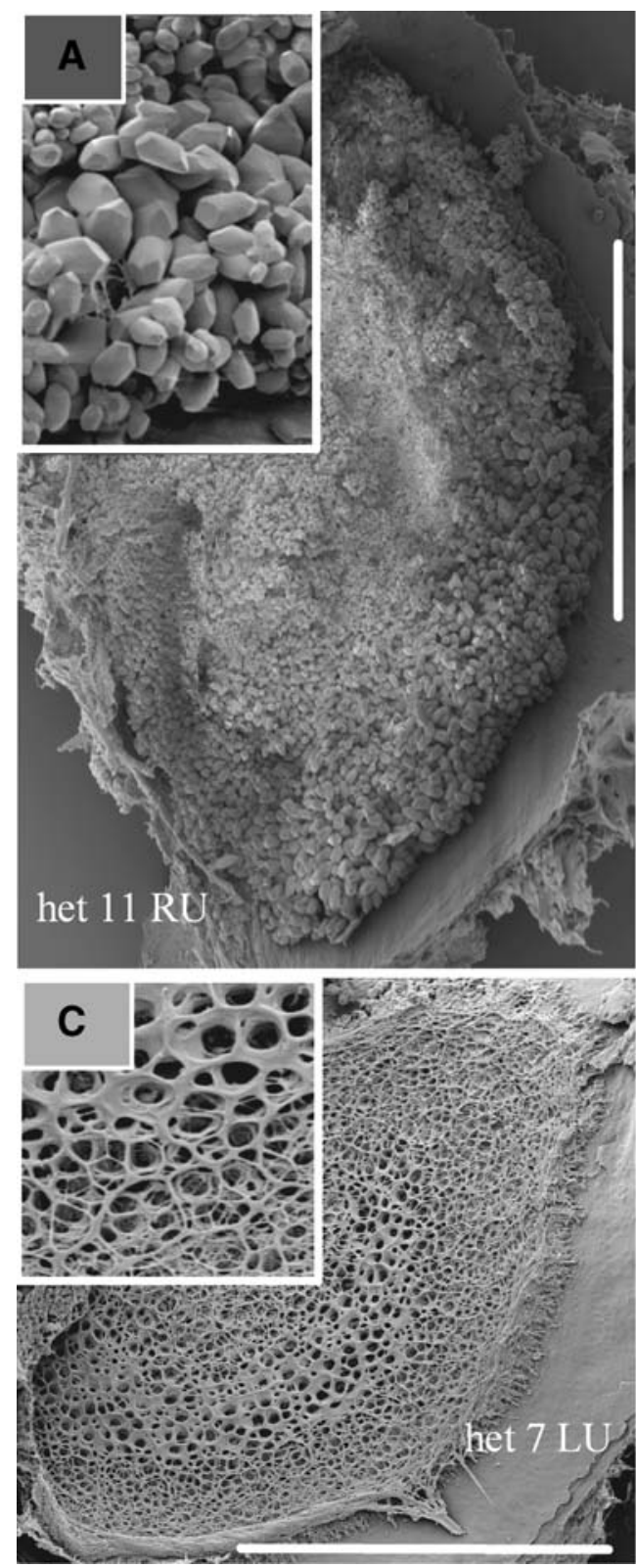

FIG. 1. A Scanning electron micrograph (SEM) of the surface of the utricular otoconial membrane from a normal mouse [OTO+, het $(+/$ $-)$ ]. Abundant otoconia are present. B SEM of the surface of the utricular otoconial membrane from an otoconial-deficient mouse

animals: het,$+- 91 / 27$; het $-/-, 57 / 16$; tlt $-/-, 56 / 21$; tlt+/-, 52/22]. Recordings of neural activity were made for up to $\sim 4.5$ min with an average duration of $43.5 \pm 21.3$ (254) seconds. We attempted to evaluate the response to rotational stimulation in 223 cells. The effectiveness of rotational stimulation in the present study is illustrated in Figure 2, which shows two cells that responded to rotation with markedly different sensitivities. It was possible to thoroughly examine the response to rotation in 152 of these cells, whereas 71 were lost before the test could be completed. Ten of the 152 tested cells $(\sim 7 \%, 10$ /

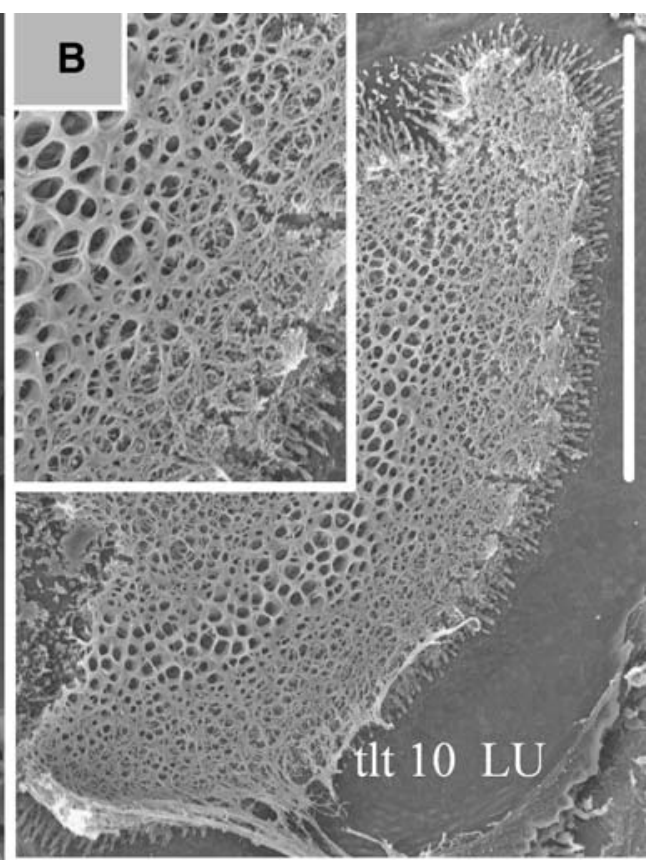

[OTO-, tlt(-/-)]. The surface is devoid of otoconia. C SEM of the surface of the utricular otoconial membrane from an otoconialdeficient mouse [OTO-, het(-/-)]. The surface is devoid of otoconia. Calibration bars equal $200 \mu \mathrm{m}$. $L U$ left utricle, $R U$ right utricle.

152) exhibited response discharge rates that modulated with rotation frequency (e.g., Fig. 2) and were identified as canal afferents. The remaining cells tested $(\sim 93 \%, 142 / 152)$ were regarded as macular neurons. Canal fibers were observed in both OTO+ and $\mathrm{OTO}^{-}$phenotypes. Resting discharge data from canal fibers were not included in the present analysis. In the case of the remaining 43 cells (i.e., 266-223), it was not possible to initiate the rotational stimulation test. Thus, in the case of 114 cells $(71+43)$, the terminal end organ (canal versus macula) was indeterminate. However, one may reason that the propor- 

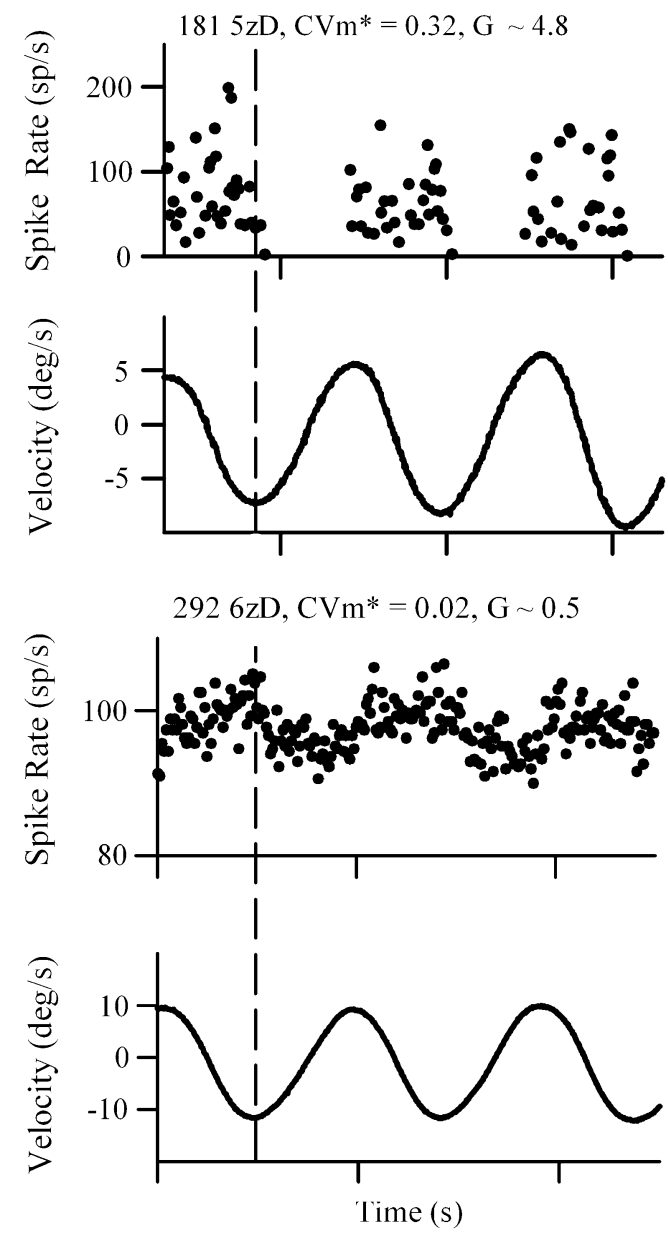

FIG. 2. Two examples of the discharge response obtained from vestibular primary afferents innervating the left horizontal crista in the present study. Cells shown were activated by counter-clockwise rotation. The figure illustrates the wide range of sensitivities evidenced by cells responding to rotation. Discharge rate $(\mathrm{sp} / \mathrm{s})$ was calculated as the reciprocal of the inter-spike interval based on the onset time of each spike discharge minus the onset time of the preceding spike. Gain $(G)$ was calculated as the mean peak-to-peak discharge rate divided by the peak-to-peak angular velocity. For stimulus plots, positive fluctuations (upward) indicate clockwise rotation, whereas negative fluctuations (downward) reflect counterclockwise rotation. Angular velocity is represented in degrees per second. The stimulus frequencies shown were approximately one cycle per second. tion of canal fibers among the indeterminate group should be similar to that found among the 152 cells fully tested (i.e., $\sim 7 \%$ ). Based on this, one can estimate that there were on the order of eight to ten canal afferents represented among the indeterminate group. It follows that summary data presented, for example, in Tables 1 and 2, may include data from eight to ten canal cells where the balance $(\sim 95 \%)$ are presumably of macular origin.

Figure 3 illustrates the resting discharge patterns of representative neurons of the superior vestibular nerve. Although these neurons were from otoconiadeficient mice, the patterns are typical for relatively regular (e.g., $\mathrm{CV}^{*}<\sim 0.1$ ) and irregular (e.g., $\mathrm{CV}^{*}>$ 0.1 ) discharge patterns found in all four genotypes. The cells of Figure 3 were unresponsive to rotational stimulation.

\section{Resting discharge rates}

Figure 4 illustrates the distribution of spike rates according to the age of animals (Fig. 4A) as well as the ages of animals in each genotype (Fig. 4B). There was no dependence of spike rate on the age of animals ( $\sim 3$ to 13 weeks old) and no significant difference in age across genotypes. The resting discharge rates of neurons from the four genetic groups of animals are summarized in Figure 5. The general distribution of spike rates was comparable for all genotypes, and the most common rates ranged between 55 and $110 \mathrm{sp} / \mathrm{s}$. Mean values of spike discharge rates are summarized in Table 1.

\section{Regularity of resting discharge}

The raw CV values and spike discharge rates for the four genotypes are shown in Figure 6. The regularity of spike discharge varied as a function of discharge rate as measured by the $\mathrm{CV}$. CV decreased with increasing spike rate, and this was true generally as well as for each genotype (regression, $p<0.001, R^{2}>$ $0.40)$. This relationship may be discerned from data

TABLE 1

\footnotetext{
Means for spike discharge rate shown are not adjusted for $\mathrm{CV}$ effects.
} 
TABLE 2

presented in Figure 6. Figure 7 illustrates CV as a function of mean discharge interval (i.e., ISI) and thus illustrates CV-ISI distributions. There were no significant differences in CV-ISI distributions across genotypes or between the two phenotypes. Figure 7 shows the pooled data for all genotypes. The solid curves on Figure 7A represent power functions describing $\mathrm{CV}$ as a function of mean interval, $t$, for five different $\mathrm{CVm}^{*}$ values including $0.025,0.05,0.1$, 0.2 , and 0.4 . The power function is given by $\mathrm{CV}=a(t)$ $\operatorname{het}(-/-)$

A

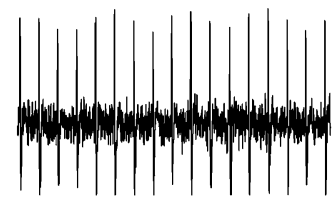

B

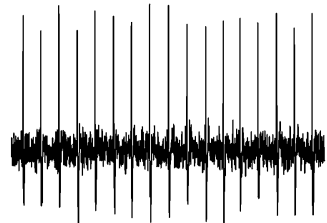

$\mathrm{C}$

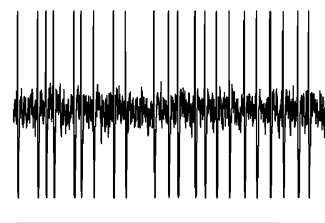

$0.2 \mathrm{~s}$ $\operatorname{tlt}(-/-)$

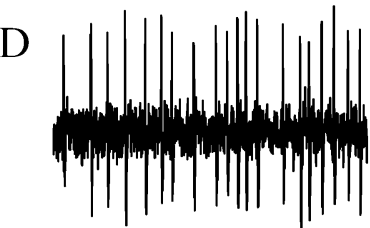

$\mathrm{E}$

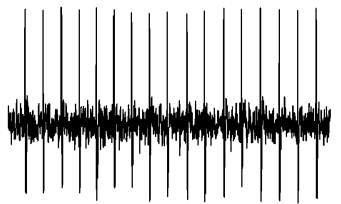

F

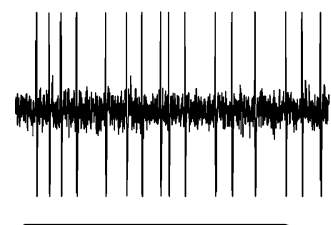

$0.2 \mathrm{~s}$
FIG. 3. Spontaneous action potential discharge records from six vestibular primary afferent neurons obtained from six otoconiadeficient mice [OTO-, het $(-/-)$, and $\mathrm{tt}(-/-)]$. Regular and irregular discharge patterns are illustrated. These cells were chosen for illustration since they were typical examples having similar discharge rates and were from animals lacking otoconia. Time is represented horizontally, and the length of time bars represent $0.2 \mathrm{~s}$. Cell designation, discharge rate $(\mathrm{sp} / \mathrm{s}), \mathrm{CVm} *$ value, and genotype are as follows: A EMV 185-3, CVm*, 0.025; rate, $67.9 \mathrm{sp} / \mathrm{s}$; het(-/-). B EMV 200-2; CVm*, 0.028; rate, 72.8sp/s; het(-/-). C EMV 201-1; CVm*, 0.524; rate, $82.0 \mathrm{sp} / \mathrm{s}$; het(-/-). D EMV 192-2; CVm*, 0.462; rate, $82.0 \mathrm{sp} / \mathrm{s} ; \mathrm{ttt}(-/-)$. E EMV 145-7; CVm*, 0.033; rate, $75.5 \mathrm{sp} / \mathrm{s}$; tlt(-/ -). F EMV 238-3; CVm*, 0.636; rate, $74.0 \mathrm{sp} / \mathrm{s}$; tlt(-/-).
$\left(\mathrm{CVm}^{*}\right)^{b(t)}$, where $a(t)$ and $b(t)$ are the coefficients for each mean interval, $t$, as determined by Lasker et al. (2008) for the mouse. The value of the mean interval for 79 cells fell outside the domain of mean intervals for which there were coefficients. These cells
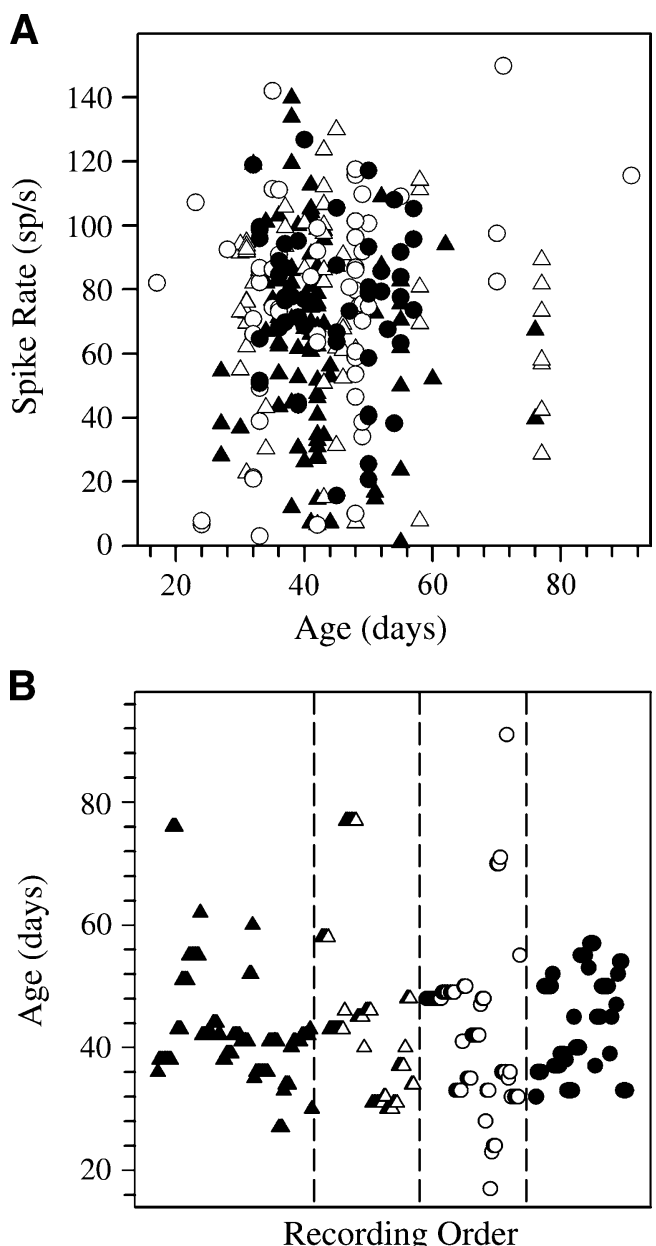

FIG. 4. Summary of mean spontaneous discharge rates $(\mathrm{sp} / \mathrm{s})$ and ages. A Summary of the mean discharge rate versus animal age. B Distribution of animal ages (days) among the four genotypes of the present study. For each genotype, the ages of cells are plotted according to the order in which they were recorded (recording order). Filled triangle het(+/-), open triangle het(-/-), open circle tlt $(-/-)$, filled circle $\mathrm{tt}(+/-)$. 

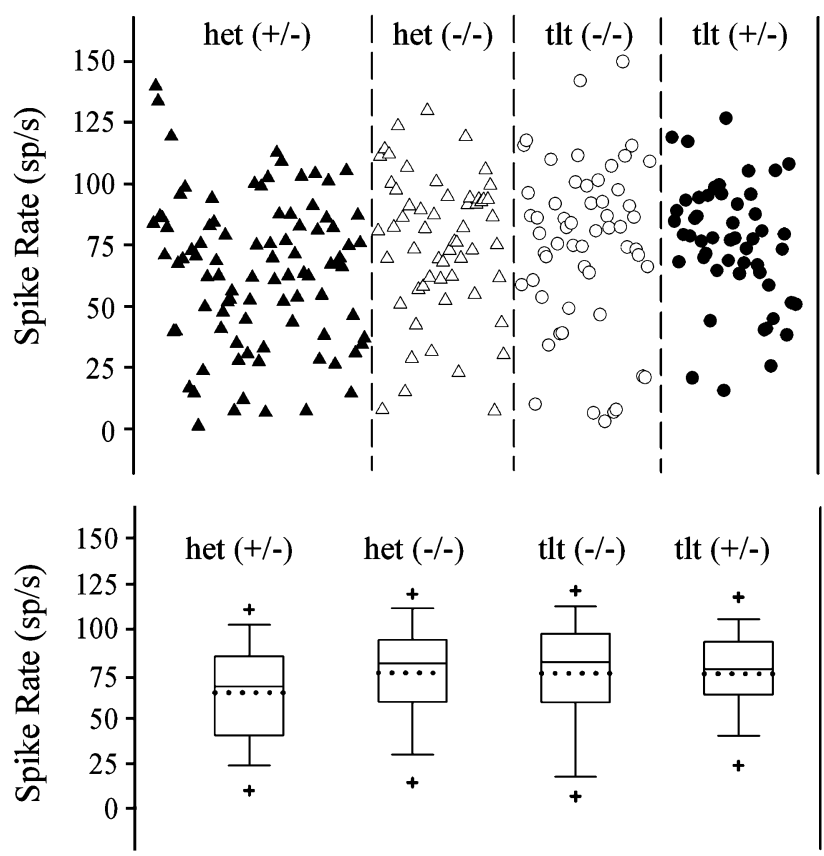

FIG. 5. Discharge rate as a function of genotype. Top Vestibular primary afferent resting discharge rates plotted in the order of their recording dates for each of four genotypes $[\mathrm{het}(+/-)$, het(-/-), $\mathrm{tt}(+/-)$, tlt(-/-)]. Lower Box plots illustrating summary statistics for each genotype. The boundary of the box closest to zero indicates the 25th percentile, a dotted line within the box marks the mean, the solid line in the box is the median, and the boundary of the box farthest from zero indicates the 75th percentile. Error bars above and below the box indicate the 90th and 10th percentiles and the plus sign marks are 5th and 95th percentiles.

therefore could not be included in $\mathrm{CVm}^{*}$ data. For this reason, we have also normalized our $\mathrm{CV}$ data using coefficients derived for chinchilla afferents by Baird et al. (1988), which include coefficients for intervals as low as $8 \mathrm{~ms}$ (Fig. 7B). Use of $\mathrm{CVc}^{*}$ permitted the inclusion of all but 17 cells. The power functions derived from each set of coefficients are shown and may be compared in Figure 7A and B. Summary descriptive statistics for $\mathrm{CVC}^{*}$ and $\mathrm{CVm}^{*}$ are listed in Table 1. In the interest of representing as many cells as possible in figures, we present $\mathrm{CVC}^{*}$ data. Similarly, $\mathrm{CVC}^{*}$ values were used to preserve sample sizes for normalized CV data in statistical tests.

General effects of normalizing CV

Figure 8 presents a summary of $\mathrm{CVc}^{*}$ (panels A-D and F) and non-normalized CV (panel E) data as a function of genotype and sequential order of measurement ( $x$ axis). $\mathrm{CVC}^{*}$ distributions were similar for each genotype in panels A-D of Figure 8. The effects of normalizing data across all cells can be seen by comparing panels $\mathrm{E}$ and $\mathrm{F}$ of Figure 8. The most prominent adjustment in $\mathrm{CV}$ values produced by normalization occurred in cells with CVs above $\sim 0.4$.
The data of Figure 8 reflected the consistency of the mouse preparation and methods used over time in that distributions remain relatively constant over the entire period of data collection.

Quantitative effects of genotype and phenotype

The results for spike discharge rates for all cells irrespective of CV are summarized in Table 1. There was a significant difference in spontaneous discharge rates across genotypes (ANOVA, $p=0.04$ ). This effect was also present after the means were adjusted for the effects of differences in $\mathrm{CVC}^{*}$ distributions among groups. Adjustment of the means was accomplished by using $\mathrm{CVC}^{*}$ as a covariate $(p<0.05$, ANOVA: spike rate by genotype with $\mathrm{CVC}^{*}$ as covariate; Keppel and Wickens 2004). Pairwise comparisons of adjusted means indicated a significant difference between het $(+/-)$ and het $(-/-)$ with higher mean discharge rates for het $(-/-)$ animals $[p=0.03]$, whereas differences between $\operatorname{tt}(+/-)$ and tlt $(-/-)$ did not reach significance.

There were no significant differences in mean discharge rates for the two strains of heterozygotes $[$ het $(+/-)$ and $\operatorname{tlt}(+/-)]$ or the two strains of homozygotes [het $(-/-)$ and tlt $(-/-)]$, thus permitting the pooling of rate data for all animals of the same phenotype (i.e., pooled OTO + or OTO- data). Comparison of the discharge rates for cells from the OTO+ and OTO - mice revealed a small but significant effect of phenotype on spike rate $(p=0.05)$. Otoconia-deficient animals had slightly higher spon-

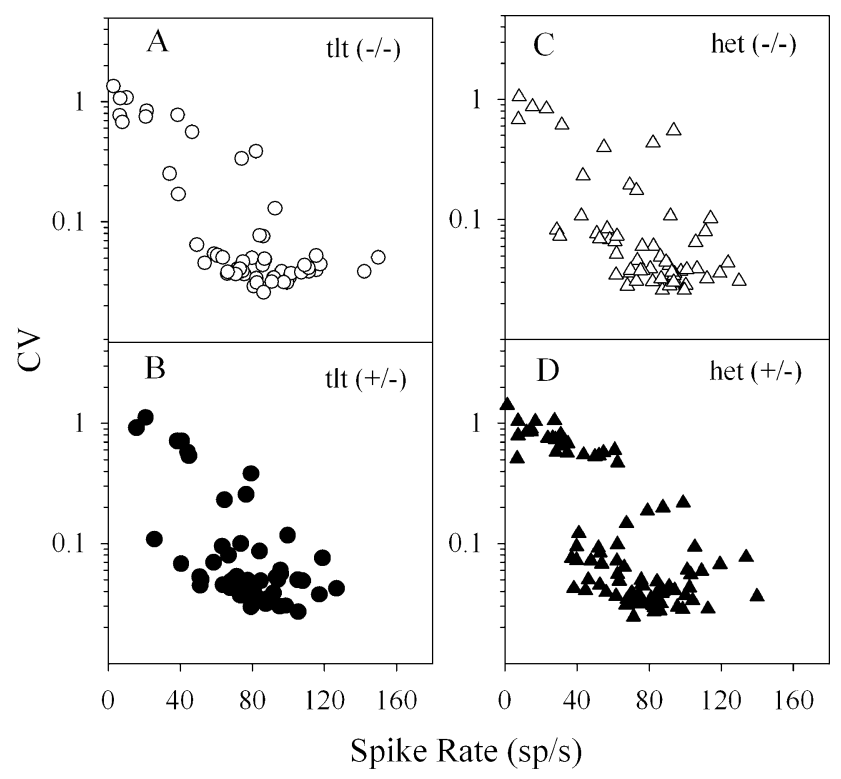

FIG. 6. Interval coefficient of variation ( $\mathrm{CV}$ ) plotted as a function of discharge rate for four genotypes [A $\mathrm{tlt}(-/-), \mathbf{B} \mathrm{ttt}(+/-), \mathbf{C}$ het(-/-), and D het(+/-)]. CV decreased with increasing discharge rate for all genotypes. There were no effects of genotype on the relationship. 

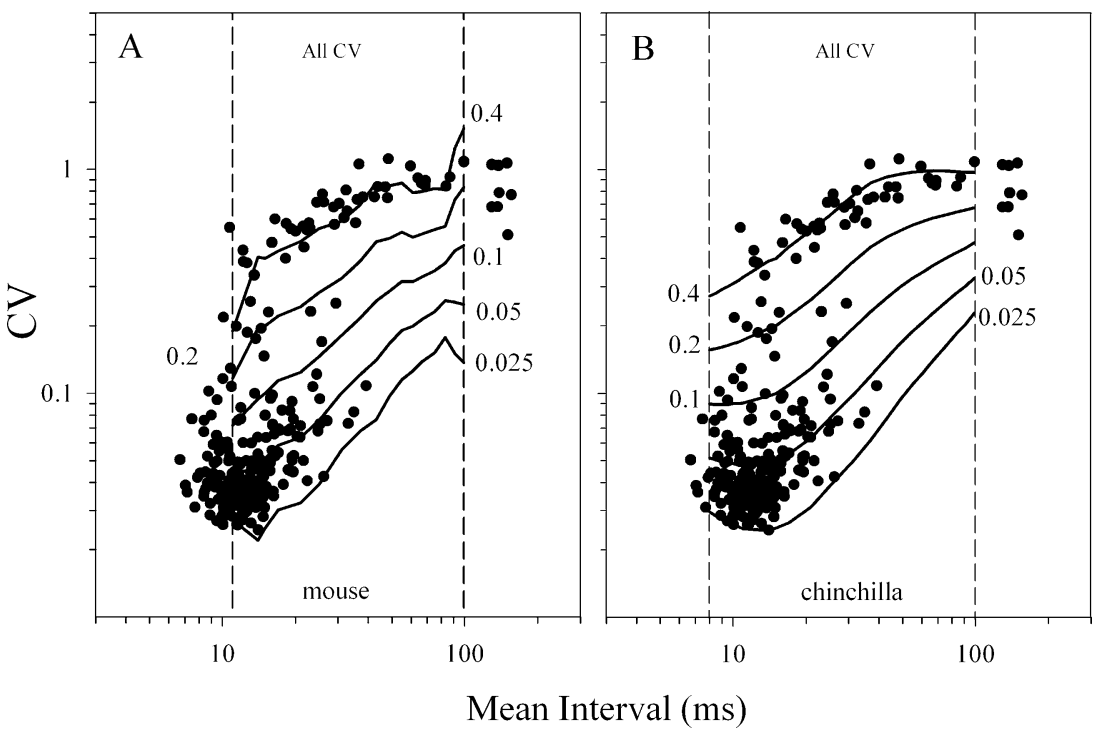

FIG. 7. Interval coefficient of variation (CV for all cells plotted as a function of discharge interval [i.e., inter-spike interval (ISI)]. The graphs illustrate the CV-ISI distribution for all cells. The solid line curves represent the power functions given by $C V=a(t)\left(C V^{*}\right)^{b(t)}$ where $a(t)$ and $b(t)$ are the coefficients determined by Lasker et. al. (2008) for the mouse (A CVm*) and by Baird et al. (1988) for the chinchilla (B CVC*). A CV are superposed with normalized iso-lines for $\mathrm{CVm}^{*}$ (mouse) where $C V=a(t)\left(C V m^{*}\right)^{b(t)}$. Iso-lines represent $C V m^{*}$ values of 0.025 ,

taneous discharge rates on average $(\mathrm{OTO}+=68.1$; OTO $-=75.4 \mathrm{sp} / \mathrm{s}$; ANOVA, $p=0.05$ see Tables 1 and 2 ), and this effect remained when differences in $\mathrm{CV}^{*} *$ distributions were taken into consideration (i.e., ANOVA, CVc* as covariate, $p=0.02)$.

Summary means for $\mathrm{CV}, \mathrm{CVC}^{*}$, and $\mathrm{CVm}^{*}$ are also shown in Tables 1 and 2. There were no differences in mean CV values or in CV-ISI distributions for the two strains of heterozygotes $[$ het $(+/-)$ and tlt $(+/-)]$ or homozygotes $[$ het $(-/-)$ and tlt $(-/-)]$, thus permit-
$0.05,0.1,0.2$, and 0.4. B CV are superposed with normalized iso-lines for $\mathrm{CV}_{\mathrm{c}}^{*}$ (chinchilla) where $\mathrm{CV}=\mathrm{a}(t)\left(\mathrm{CV}_{\mathrm{c}}^{*}\right)^{b(t)}$. Lines for $\mathrm{CV}_{\mathrm{c}}^{*}$ values of $0.025,0.05,0.1,0.2$, and 0.4 are shown. Vertical dashed lines mark the limiting range of discharge intervals available for the mouse (A) and chinchilla (B). CV values lying outside interval ranges could not be normalized. Coefficients available for the chinchilla (B) afforded the maximum number of normalized CV.

ting the combining of $\mathrm{CV}$ data for all animals of the same phenotype (OTO+ or OTO-). There was also no effect of phenotype on the mean values of $\mathrm{CVC}^{*}$ or on $\mathrm{CVC}^{*}-\mathrm{ISI}$ distributions.

Frequency distributions of $\mathrm{CVc}^{*}$

The frequency distributions of normalized CVc* values are presented graphically in Figure 9. In normal animals $(\mathrm{OTO}+), \mathrm{CVc}^{*}$ was distributed in a

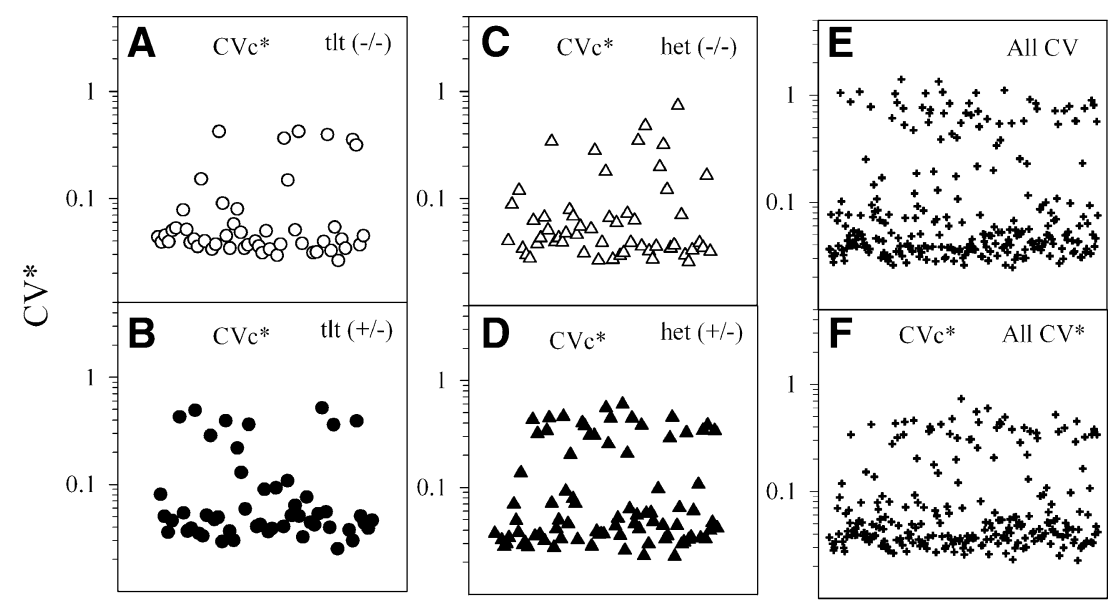

Recording Order

FIG. 8. Normalized coefficient of variation values $\left(\mathrm{CV}^{*}\right)$ for each genotype plotted according to the order in which they were recorded. A-D $\mathrm{CVC}^{*}$ for $\mathrm{ttt}(-/-)$, tlt(+/-), het(-/-), and het(+/-), respectively. E All non-normalized CV. F All normalized CVC* values. Note the effects of normalization by comparing plots for $\mathbf{E}$ and $\mathbf{F}$. 


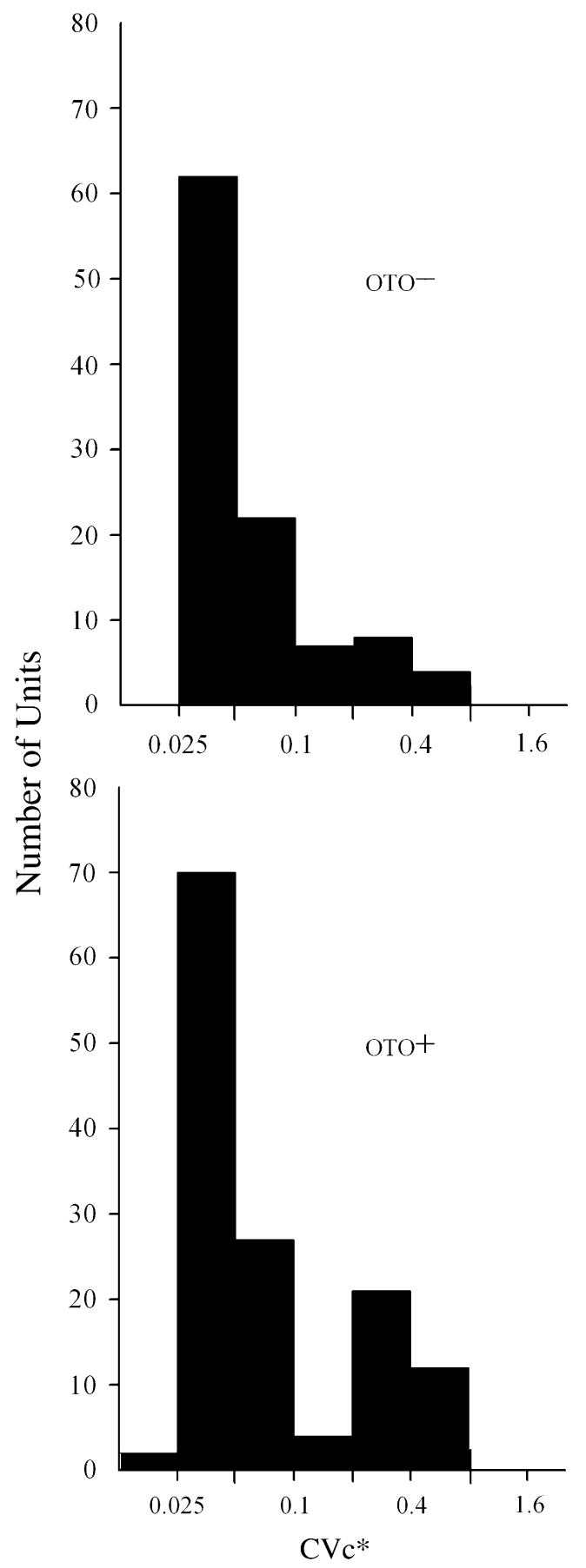

FIG. 9. Distributions for $\mathrm{CV}_{\mathrm{c}}^{*}$ values of otoconia-deficient (top OTO-) and normal (bottom OTO+) mice. Bars indicate the number of cells having $\mathrm{CV}_{\mathrm{C}}^{*}$ values falling within each corresponding bin range. The lower limit of each bin $(B i)$ is given by the following: for each bin, $i=1,2, \ldots, 8 ; \mathrm{Bi}=0.00625\left(2^{i}\right)$, i.e., $0.025,0.5,0.1,0.2,0.4$, 0.8 , and 1.6 .

clear bimodal pattern, where the largest number of $\mathrm{CVC}^{*}$ values were below 0.1 . The second peak of the bimodal distribution fell in the region between 0.2 and 0.8. The $\mathrm{CVC}^{*}$ distribution in otoconia-deficient animals (OTO-) was somewhat different in that there tended to be only one major peak, which was formed by cells having $\mathrm{CVc}^{*}$ below 0.1 . For CVc*'s above 0.1 , there were fewer numbers of cells overall compared to normal animals, and the counts distributed rather evenly between 0.1 and 0.8 . The two $\mathrm{CVc}^{*}$ distributions $\left(\mathrm{OTO}+\right.$ vs $\left.\mathrm{OTO}^{-}\right)$were significantly different $\left(\chi^{2} ; p<0.01\right)$, and the difference suggested that there were proportionately fewer irregular fibers $\left(\mathrm{CVc}^{*}>\right.$ 0.1 ) among the cells of the OTO- animals. A summary of $\mathrm{CV}$ data grouped according to traditional regular $\left(\mathrm{CV}^{*} \leq 0.1\right)$ and irregular $\left(\mathrm{CV}^{*}>0.1\right)$ categories is provided in Table 2.

\section{DISCUSSION}

Injection of label into the superior vestibular nerve resulted in labeled dendrites located in the utricle, sacculus, and cristae of the superior and horizontal canals. Despite a notable projection from the superior vestibular nerve to the two cristae, a very large proportion of cells of the present study proved unresponsive to rotational stimuli. This suggests that the electrode size and trajectory typically used to isolate cells in our studies preferentially sampled cells innervating the maculae. Among those cells thoroughly tested by rotational stimulation, $\sim 93 \%$ were unresponsive and likely of macular origin. We interpret these findings to mean that a substantial number, if not a preponderance of fibers studied in the present report, were macular afferents. Furthermore, since all of these cells were active, the results in OTO- mice provide convincing evidence that, in the absence of stimulation, macular primary afferents exhibit robust spontaneous discharge. This finding confirms the consensus hypothesis that resting macular activity arises from mechanisms that are ultimately independent of external stimulation.

The source of tonic excitation and resting discharge

As noted in "Introduction," there is considerable evidence that the spontaneous discharge of inner ear and lateral line primary afferent neurons arises from a steady excitation due to calcium-dependent background release of neurotransmitter from presynaptic hair cells. We have shown recently that the synaptic machinery is present in otoconia-deficient mice, from which, a tonic excitatory drive could arise (Hoffman et al. 2006). The present results suggest further that these synapses are functional, inasmuch as the primary afferents exhibit robust spontaneous activity with high rates of discharge. Together, the observations in otoconia-deficient mice are consistent with the traditional view that spontaneous macular ganglion cell discharge depends critically on a tonic 
resting excitatory drive arising from presynaptic hair cells and does not depend on external stimulation.

The alternative view holds that tonic vestibular afferent discharge arises independently in the ganglion cell itself without the requirement for excitatory drive from the hair cell. Reports of spontaneous vestibular discharge in vitro (Desmadryl et al. 1986) and following hair cell destruction (e.g., Hirvonen et al. 2005) have been cited as evidence in support of this alternative hypothesis. However, these studies did not evaluate ganglion cells in the absence of hair cells and, therefore, do not address the question of isolated independent ganglion cell discharge. To our knowledge, the study by Lin and Chen (2000) provides the only evidence that eighth nerve ganglion cells are capable of spontaneous discharge in the absence of hair cells. In this case, isolated auditory spiral ganglion cells of neonatal mice were shown to be capable of slow $(<10 \mathrm{sp} / \mathrm{s})$ irregular spontaneous activity. However, the capacity for such independent activity reportedly was not present in adult animals (Lin and Chen 2000; Santos-Sacchi 1993) nor was activity present in isolated vestibular ganglion cells even in the neonate (2006). Hence, the capacity for independent discharge, if such a phenomenon could exist at all in vivo, would be restricted to neonatal auditory ganglion cells and be manifested as very low rate irregular spike discharge.

The very nature of the animals and patterns of vestibular activity in OTO- mice appear to rule against the alternative hypothesis: (1) Our results were obtained in vestibular afferents and in adult animals, (2) discharge rates were well above $25 \mathrm{sp} / \mathrm{s}$ in the vast majority of cells, and (3) the ganglion cells were not isolated from hair cells but rather have been shown to form terminal dendritic ribbon synapses with hair cells (Hoffman et al. 2006). These facts make it highly unlikely that the discharge characteristics observed in vestibular primary afferents of OTO - mice arose independently of tonic excitation by hair cells. Indeed, the complex nature of spontaneous discharge reported for OTO- animals in our view simply cannot be explained on the basis of activity patterns reported for physically isolated eighth nerve ganglion cells.

Resting discharge regularity and rates in mice

The range of normalized $\mathrm{CV}^{*}$ values obtained from mice of the present study is comparable to that reported for mouse canal afferents (Lasker et al. 2008; Yang and Hullar 2007). The range of CVs as well as the mean $\mathrm{CV}$ for the OTO+ data closely approximate those reported in Figure 1 of Yang and Hullar (2007) for "wild-type" C57 mice (no significant difference, $p>0.2$ ). Moreover, there is no significant difference in the distribution of CV-ISI pairs obtained from normal mice of the two studies (i.e., OTO+ mice in the present study and C57 wild-type mice; Yang and Hullar 2007; chi-square, $p=0.1$ ). Thus, the features of discharge regularity exhibited by vestibular afferents in the present study are not statistically different from those reported for normal mice elsewhere.

The resting discharge rates reported here (Table 1 , OTO+: mean, $\sim 68 \mathrm{sp} / \mathrm{s}$ ) are somewhat higher than those reported for mice by Yang and Hullar (2007; mean, $\sim 56 \mathrm{sp} / \mathrm{s}$; significantly different, $p<0.001)$ and by Lasker et. al. (2008, estimated mean $<55 \mathrm{sp} / \mathrm{s}$ ). On the other hand, rates observed here are more comparable to those reported for other mammals (e.g., for superior nerve macular neurons, means $\sim 66 \mathrm{sp} / \mathrm{s}$ : Baird et al. 1988; Fernandez and Goldberg 1976a; Goldberg et al. 1984; Goldberg and Fernandez 1971a). The basis of the rate differences across studies in mice is not clear. Core temperatures were held somewhat higher in the present study, and we report results for macular afferents rather than canal afferents. These factors may contribute to the differences in discharge rates reported.

\section{Discharge regularity}

Resting or "spontaneous" discharge patterns for vestibular primary afferents are generally thought of as being of two basic types, irregular or regular, with a number of distinct physiological response attributes associated with each type (e.g., Baird and Lewis 1986; Fernandez and Goldberg 1976a, b; Goldberg et al. 1984; Goldberg and Fernandez 1971b). For any given vestibular neuron, CV can vary considerably as illustrated by the power functions of $\mathrm{CV}$ versus mean inter-spike interval in Figure 7. This complex behavior of CV is not seen in all sensory neurons innervating hair cells. Cochlear ganglion cells do not show a diversity of discharge regularity. There are no "regular" spontaneous firing patterns in normal auditory ganglion cells. Therefore the values of CV's for auditory neurons are all above $\sim 0.5$ but most are near 1.0 in the adult (Jones et al. 2007; Jones and Jones 2000; Kiang 1965; Walsh et al. 1972). Furthermore, in auditory neurons, CV is not a function of spike rate (Jones et al. 2007; Jones and Jones 2000). Thus, despite having the shared features of (1) innervating a non-neural receptor cell and (2) exhibiting spontaneous discharge, there are fundamental differences in the discharge characteristics of auditory and vestibular fibers. This suggests that one needs more than just a hair cell and a ribbon synapse to produce spontaneous discharge characteristics matching those of the normal vestibular system. In this context, it is notable that the discharge characteristics of macular afferents in otoconia-deficient ani- 
mals exhibited the full range of $\mathrm{CV}^{*}$ values found in normal mammals and thus shared this characteristically vestibular feature.

Although the range of $\mathrm{CVC}^{*}$ values for OTO+ and OTO- were similar, there was a small quantitative difference in the frequency distribution of $\mathrm{CVC}^{*}$ that suggested OTO- mice had proportionately fewer irregular fibers (Fig. 9). The importance of this difference is not immediately clear since variation in $\mathrm{CV}^{*}$ distributions are common in the literature, and it may simply reflect routine variability in sampling.

The role of tonic vestibular input to the mature central nervous system

The steady background discharge activity of vestibular ganglion cells is transmitted to post-synaptic neural circuits centrally. It is well known that this tonic discharge activity has a powerful influence on motor control systems in the brainstem (Goldberg 2000; Goldberg and Fernandez 1984; e.g., Precht et al. 1966). Less well appreciated is the fact that tonic gravity receptor discharge may strongly influence regulatory systems located in the brainstem and at more rostral levels of the neuraxis in mature animals (e.g., Fuller et al. 2002, 2004; Xue et al. 2004; Yates and Miller 1998). The findings of elevated discharge rates in OTO- mice may have a bearing on altered baroreflexes reported for these animals [in het $(-/-)$ mice, Xue et al. 2004] and may help explain the tonic vestibular influence inferred by these authors as well as the slightly elevated baseline heart rates reported.

Discharge rates and the unloaded macula

When animals are exposed to whole-body centrifugation on large diameter centrifuges, the gravitational load on macular sensory elements is increased. The result is an increased level of tonic vestibular discharge and in turn increased levels of activity in central vestibular relays (Fuller et al. 2002, 2004; Kaufman et al. 1992; Murakami et al. 2002). Similar changes have been reported during space flight with increases and decreases in gravitational loading (Pompeiano et al. 2001a, b).

Whether these changes in discharge level translate into altered background resting discharge rates during gravitational unloading and loading is an interesting open question for which our results may have some bearing. Based on the studies cited above, one might reason simply that mean ganglion cell discharge rates should increase or decrease respectively with increased or decreased macular gravitational loading. However, this notion was not borne out in the present study. Neither overall rates nor the range of rates were reduced (see Fig. 5 and Tables 1 and 2) in otoconia-deficient mice compared to normal animals, as would be predicted on the basis of an unloaded macula. However, our results were obtained under conditions of long-term chronic unloading of the macula unlike the short-term (hours to days) load changes cited. In the absence of ambient gravitational loading, indeed in the absence of any stimulus, macular discharge rates on average slightly exceeded those of animals loaded normally at $1 \mathrm{G}$. These findings suggest to us that discharge rates may be regulated such that, when disturbed (e.g., by unloading or loading) or in the absence of all stimulation, a long-term adaptive process ultimately acts to bring mean macular discharge rates toward some set point at or near normal levels in the chronic stages of unloading. Hypothetically, this putative adaptive process would have a much longer time constant $(\tau \gg$ minutes) and different origins than those underlying the well-appreciated mechanotransduction adaptation mechanisms (see reviews, Eatock 2000, Eatock and Lysakowski 2006, Fettiplace and Ricci 2006, and Hudspeth and Gillespie 1994). The exact nature of the hypothesized long-term adaptive process is not clear.

Adaptation in the synaptic apparatus is one possible mechanism that could account for the increased discharge rates reported here. Ross (1993, 1994, and 2000) reported that the number of macular ribbon synapses changed over a period of days following changes in gravitational loading. Her findings provided evidence that the synaptic apparatus may be regulated in response to long-term gravitational unloading. Since, OTO- mice present chronically unloaded maculae, one might reason that the synaptic apparatus in OTO- mice should provide evidence of up-regulation. Indeed, there is some qualitative support for this suggestion.

Hoffman et al. (2006) noted a prevalence of multiple ribbon complexes in type II hair cells from OTO- utricles. Such synaptic ribbon complexes are uncommon in the adult rodent utricle and were found to be restricted to type I hair cells in the mouse vestibular neuroepithelia (Park et al. 1987). They are, however, found in the developing (i.e., E19) mouse utricle (Fig. 17 in Van De Water et al. 1977) and were reported to occur in greater numbers in early neonatal compared to older (e.g., P28) mice (Lysakowski 1999). The relatively frequent occurrence of multiple ribbon complexes among hair cells of the utricular neuroepithelium of the OTO- mouse may reflect adaptive changes to chronic sensory deprivation (unloading). A quantitative evaluation of ribbon synapses in OTO- mice would be helpful in providing a definitive answer to this question. 


\section{SUMMARY}

The present results demonstrate that vestibular primary afferents innervating otoconia-deficient maculae are spontaneously active, discharge at slightly higher rates on average, and otherwise evidence a range of variation in discharge regularity comparable to that found in normal control mice and other mammals. These findings confirm the hypothesis that resting activity in macular primary afferents occurs in the absence of ambient stimulation and suggest indirectly that the ribbon synapses present in hair cells of otoconia-deficient mice are functional.

\section{ACKNOWLEDGMENT}

This work was supported by NIH NIDCD R01 DC005776 and by NASA RPG: Human Health From Earth to Space: A NASA-MU Partnership for Understanding Sex Differences in Physiology: Project 1D (TAJ). We would like to thank Fiona Foley, Michael Hartsock, Jack Hill, Melissa Jensen, and Bruce Mock for their excellent assistance in the lab. We also thank T. Huller, L. Minor, and D. Lasker for providing normative data on spontaneous discharge rates and CVs from wild-type C57 mice and R. Boyle for discussions on rotary bearings for stimulus tables.

\section{REFERENCES}

ADRIAN ED. Discharges from vestibular receptors in the cat. J. Physiol. (Lond.) 101:389-407, 1943.

anastasio TJ, Correia MJ, Perachio AA. Spontaneous and driven responses of semicircular canal primary afferents in the unanesthetized pigeon. J. Neurophysiol. 54:335-347, 1985.

Annoni JM, Cochran SL, Precht W. Pharmacology of the vestibular hair cell-afferent fiber synapse in the frog. J. Neurosci. 4:21062116, 1984.

BAIRD RA, LEwIS ER. Correspondences between afferent innervation patterns and response dynamics in the bullfrog utricle and lagena. Brain Res. 369:48-64, 1986.

BAIRD RA, SCHuFf NR. Peripheral innervation patterns of vestibular nerve afferents in the bullfrog utriculus. J. Comp. Neurol. 342:279-298, 1994.

Baird RA, Desmadryl G, Fernandez C, Goldberg JM. The vestibular nerve of the chinchilla. II. Relation between afferent response properties and peripheral innervation patterns in the semicircular canals. J. Neurophysiol. 60:182-203, 1988.

Bergstrom RA, You Y, Erway LC, Lyon MF, Schimenti JC. Deletion mapping of the head tilt (het) gene in mice: a vestibular mutation causing specific absence of otoliths. Genetics 150:815-822, 1998.

Desmadryl G, Raymond J, SANS A. In vitro electrophysiological study of spontaneous activity in neonatal mouse vestibular ganglion neurons during development. Dev. Brain Res. 25:133-136, 1986.

Dickman JD, Angelaki DE, Correia MJ. Response properties of gerbil otolith afferents to small angle pitch and roll tilts. Brain Res. 556:303-310, 1991.

EАтоск RA. Adaption in hair cells. Annu. Rev. Neurosci. 23:285-314, 2000.
EATOCK RA, Lysakowski A. Mammalian vestibular hair cells. In: Eatock RA, Fay RR, Popper AN (eds) Vertebrate Hair Cells. New York, Springer, pp. 348-441, 2006.

Fernandez C, Goldberg JM. Physiology of peripheral neurons innervating otolith organs of the squirrel monkey. I. Response to static tilts and to long-duration centrifugal force. J. Neurophysiol. 39:970-984, 1976a.

Fernandez C, Goldberg JM. Physiology of peripheral neurons innervating otolith organs of the squirrel monkey. III. Response dynamics. J. Neurophysiol. 39:996-1008, 1976b.

Fernandez C, Goldberg JM, Abend WK. Response to static tilts of peripheral neurons innervating otolith organs of the squirrel monkey. J. Neurophysiol. 35:978-997, 1972.

Fernandez C, Baird RA, Goldberg JM. The vestibular nerve of the chinchilla. I. Peripheral innervation patterns in the horizontal and superior semicircular canals. J. Neurophysiol. 60:167-203, 1988.

Fernandez C, Goldberg JM, Baird RA. The vestibular nerve of the chinchilla. III. Peripheral innervation patterns in the utricular macula. J. Neurophysiol. 63:767-780, 1990.

FEtTIPLACE R, RicCI AJ. Mechanoelectrical transduction in auditory hair cells. In: Eatock RA, Fay RR, Popper AN (eds) Vertebrate Hair Cells. New York, Springer, pp. 154-203, 2006.

FitzGerald M. Spontaneous and evoked activity of fetal primary afferents in vivo. Nature 326:603-605, 1987.

Fitzgerald M, Fulton BP. The physiological properties of developing sensory neurons. In: Scott SA (ed) Sensory Neurons: Diversity, Development, and Plasticity. New York, NY, Oxford University Press, pp. 287-306, 1992.

Flock A, Russel I. Inhibition by efferent nerve fibres: action on hair cells and afferent synaptic transmission in the lateral line canal organ of the burbot Lota lota. J. Physiol. 257:45-62, 1976.

Fuchs PA, PARsons TD. The synaptic physiology of hair cells. In: Eatock RA, Fay RR, Popper AN (eds) Vertebrate Hair Cells. New York, Springer, pp. 249-312, 2006.

Fuller PM, JONes TA, Jones SM, Fuller CA. Neurovestibular modulation of circadian and homeostatic regulation: a vestibulo-hypothalamic connection? Proc. Natl. Acad. Sci. 99:1572315728, 2002.

Fuller PM, Jones TA, Jones SM, Fuller CA. Evidence for macular gravity receptor modulation of hypothalamic, limbic and autonomic nuclei. Neuroscience 129:461-471, 2004.

FurukaWA T, IshII Y. Neurophysiological studies on hearing in goldfish. J. Neurophysiol. 30:1377-1403, 1967.

FurukaWa T, IshiI Y, Matsuura S. Synaptic delay and time course of postsynaptic potentials at the junction between hair cells and eighth nerve fibers in the goldfish. Jpn. J. Physiol. 22:617-635, 1972.

GoldBerg JM. Afferent diversity and the organization of central vestibular pathways. Exp. Brain Res. 130:277-297, 2000.

Goldberg JM, Fernandez C. Physiology of peripheral neurons innervating semicircular canals of the squirrel monkey. I. Resting discharge and response to constant angular accelerations. J. Neurophysiol. 34:635-660, 1971a.

Goldberg JM, Fernandez C. Physiology of peripheral neurons innervating semicircular canals of the squirrel monkey. III. Variations among units in their discharge properties. J. Neurophysiol. 34:676-684, 1971b.

Goldberg JM, Fernandez C. Response of peripheral vestibular neurons to angular and linear accelerations in the squirrel monkey. Acta Otolaryngol. (Stockh) 80:101-110, 1975.

GoldBerg JM, Fernandez C. The vestibular system. In: Brookhart JM, Mountcastle VB (eds) The Nervous System: Sensory Processes, Part 2. Bethesda, MA, American Physiological Society, pp. 977 1022, 1984

Goldberg JM, Fernandez C, Smith CE. Responses of vestibular-nerve afferents in the squirrel monkey to externally applied galvanic currents. Brain Res. 252:156-160, 1982. 
Goldberg JM, Smith CE, Fernandez C. Relation between discharge regularity and responses to externally applied galvanic currents in vestibular nerve afferents of the squirrel monkey. J. Neurophysiol. 51:1236-1256, 1984.

Goldberg JM, Desmadryl G, Baird RA, Fernandez C. The vestibular nerve of the chinchilla. IV. Discharge properties of utricular afferents. J. Neurophysiol. 63:781-790, 1990a.

Goldberg JM, Desmadryl G, Baird RA, Fernandez C. The vestibular nerve of the chinchilla. V. Relation between afferent discharge properties and peripheral innervation patterns in the utricular macula. J. Neurophysiol. 63:791-804, 1990b.

Harris GG, Flock A. Spontaneous and evoked activity from the xenopus laevis lateral line. In: Cahn $\mathrm{PH}$ (ed) Lateral Line Detectors. Bloomington, IN, Indiana University Press, pp. 135$161,1967$.

HaRris GG, Milne DC. Input-output characteristics of the lateral line sense organs of Xenopus laevis. J. Acoust. Soc. Am. 40:32-42, 1965.

Hirvonen TP, Minor LB, Hullar Te, Carey JP. Effects of intratympanic gentamicin on vestibular afferents and hair cells in the chinchilla. J. Neurophysiol. 93:643-655, 2005.

Hoffman LF, Ross MD, Varelas J, Jones SM, Jones TA. Afferent synapses are present in utricular hair cells from otoconiadeficient mice. Hear. Res. 222:35-42, 2006.

HofFman LF, Hu R, Jones TA. Dendritic arbor architecture within the murine utricle. Association for Research in Otolaryngology, 30, 2007a.

Hoffman LF, Siegerman C, Su D, Jones TA. Spatial distribution of utricular hair cell mophologic polarization vectors: role of natural stimuli. Association for Research in Otolaryngology, 30, $2007 \mathrm{~b}$.

Holt JC, Xue J-T, Brichta AM, Goldberg JM. Transmission between type II hair cells and bouton afferents in the turtle posterior crista. J. Neurophysiol. 95:428-452, 2006.

Holt JC, Chatlani S, Lysakowski A, Goldberg JM. Quantal release and nonquantal transmission in calyx-bearing fibers of the turtle posterior crista. J. Neurophysiol. 98:1083-1101, 2007.

HuDSPETH AJ. The ionic channels of a vertebrate hair cell. Hear. Res. 22:21-27, 1986.

Hudspeth AJ, Gillespie PG. Pulling springs to tune transduction: adaptation by hair cells. Neuron 12:1-9, 1994.

Hullar te, Della Santina CC, Hirvonen T, Lasker dM, Carey JP, MINOR LB. Responses of irregularly discharging chinchilla semicircular canal vestibular-nerve afferents during high-frequency head rotations. J. Neurophysiol. 93:2777-2786, 2005.

Hurle B, Lane K, Kenney J, Tarantino LM, Bucan MBBH, Ornitz DM. Physical mapping of the mouse tilted locus identifies an association between human deafness loci DFNA6/14 and vestibular system development. Genomics 77:189-199, 2001.

Hurle B, Ignatova E, Massironi SM, Mashimo T, Rios X, Thalmann I, Thalmann R, Ornitz DM. Non-syndromic vestibular disorder with otoconial agenesis in tilted/mergulhador mice caused by mutations in otopetrin 1. Hum. Mol. Genet. 12:777-789, 2003.

Ishit Y, Matsuura S, Furukawa T. Quantal nature of transmission at the synapse between hair cells and eighth nerve fibers. Jpn. J. Physiol. 21:79-89, 1971.

Jones SM, Jones TA. Neural tuning characteristics of auditory primary afferents in the chicken embryo. Hear. Res. 82:139$148,1995 \mathrm{a}$

JoNes SM, Jones TA. The tonotopic map in the embyronic chick cochlea. Hear. Res. 82:149-157, 1995b.

Jones TA, Jones SM. Spontaneous activity in the statoacoustic ganglion of the chicken embryo. J. Neurophysiol. 83:1452$1468,2000$.

Jones SM, Erway LC, Bergstrom RA, Schimenti JC, Jones TA. Vestibular responses to linear acceleration are absent in otoconia-deficient C57BL/6JEi-het mice. Hear. Res. 135:56-60, 1999.

Jones TA, Jones SM, Paggett KC. Primordial rhythmic bursting in embryonic cochlear ganglion cells. J. Neurosci. 21:8129-8135, 2001.

Jones SM, ERwAY LC, Yu H, Johnson KR, Jones TA. Gravity receptor function in mice with graded otoconial deficiencies. Hear. Res. 191:34-40, 2004.

Jones TA, Jones SM, PAggett KC. Emergence of hearing in the chicken embryo. J. Neurophysiol. 96:128-141, 2006.

Jones TA, Leake PA, Snyder RL, Stakhovskaya O, Bonham B. Spontaneous discharge patterns in cochlear spiral ganglion cells prior to the onset of hearing in cats. J. Neurophysiol. 98:1898-1908, 2007.

Katz B. The Release of Neural Transmitter Substances. Liverpool, University Press, pp. 1-59, 1969.

Kaufman GD, Anderson JH, Beitz AJ. Fos-defined activity in rat brainstem following centripetal acceleration. J. Neurosci. 12:4489-4500, 1992.

Keppel G, Wickens TD. Design and Analysis, A Researcher's Handbook. New Jersey, Pearson/Prentice Hall, pp. 1-612, 2004.

KIang NYS. Discharge Patterns of Single Fibers in the Cat's Auditory Nerve. Cambridge, MIT Press, pp. 1-154, 1965.

Kiang NYS, Liberman MC, Levine RA. Auditory nerve activity in cats exposed to ototoxic drugs and high intensity sounds. Ann. Otol. Rhinol. Laryngol. 85:752-768, 1976.

Lasker DM, Han GC, PARK HJ, Minor LB. Rotational responses of vestibular-nerve afferents innervating the semicircular canals in the C57BL/6 mouse. J. Assoc. Res. Otolaryngol. (in press), 2008. doi:10.1007/s10162-008-0120-4.

Li W, CoRreia MJ. Recovery of semicircular canal primary afferent activity in the pigeon after streptomycin ototoxicity. J. Neurophysiol. 80:3297-3311, 1998.

Lim DJ, ERway LC, CLark DL. Tilted-head mice with genetic otoconial anomaly. Behavioral and morphological correlates. In: Hood JD (ed) Vestibular Mechanisms in Health and Disease. London, Academic, pp. 195-206, 1978.

Lin X, Chen S. Endogenously generated spontaneous spiking activities recorded from postnatal spiral ganglion neurons in vitro. Dev. Brain Res. 119:297-305, 2000.

Loe PR, Tomko DL, Werner G. The neural signal of angular head position in primary afferent vestibular nerve axons. J. Physiol. 230:29-50, 1973.

LySAKOWSKI A. Development of synaptic innervation in the rodent utricle. Ann. N. Y. Acad. Sci. 871:422-425, 1999.

Manley GA, Haeseler C, Brix J. Innervation patterns and spontaneous activity of afferent fibres to the lagenar macula and apical basilar papilla of the chick's cochlea. Hear. Res. 56:211-226, 1991.

Muller M, Smolders JWT, Ding-PFennigdorff D, Klinke R. Discharge properties of pigeon single auditory nerve fibres after recovery from severe acoustic trauma. Int. J. Dev. Neurosci. 15:401-416, 1997.

Murakami DM, Erkman L, Hermanson O, Rosenfeld MG, Fuller CA. Evidence for vestibular regulation of autonomic functions in a mouse genetic model. Proc. Natl. Acad. Sci. 99:17078-17082, 2002.

Ornitz DM, Bohne BA, Thalmann I, Harding GW, Thalmann R. Otoconial agenesis in tilted mutant mice. Hear. Res. 122:60-70, 1998.

Paffenholz R, Bergstrom RA, Pasutto F, Wabnitz P, Munroe RJ, Jagla W, Heinzmann U, Marquardt A, Bareiss A, Laufs J, Russ A, Stumm G, Schimenti JC, Bergstrom DE. Vestibular defects in head-tilt mice result from mutations in Nox3, encoding an NADPH oxidase. Genes. Dev. 18:486-491, 2004.

Park JC, Hubel SB, Woods AD. Morphometric analysis and fine structure of the vestibular epithelium of aged C57BL/6NNia mice. Hear. Res. 28:87-96, 1987. 
Pompeiano M, d’Ascanio P, Centini C, Pompeiano O, Cirelli C, Tononi G. Fos-related antigens are involved in the transcriptional responses of locus coeruleus neurons to altered gravitational fields in rats. Acta Otolaryngol. Suppl. (Stockh.) 545:127-132, 2001 .

Pompeiano O, D’Ascanio P, Centini C, Pompeiano M, Cirelli C, TonONi G. Immediate early gene expression in the vestibular nuclei and related vegetative areas in rats during space flight. Acta Otolaryngol. Suppl. (Stockh.) 545:120-126, 2001b.

Precht W, Shimazu H, Markham CH. A mechanism of central compensation of vestibular function following hemilabyrinthecomy. J. Neurophysiol. 29:996-1010, 1966.

Risner JR, Holt JR. Heterogeneous potassium conductances contribute to the diverse firing properties of postnatal mouse vestibular ganglion neurons. J. Neurophysiol. 96:2364-2376, 2006.

Ross MD. Morphological changes in rat vestibular system following weightlessness. J. Vestib. Res. 3:241-251, 1993.

Ross MD. A spaceflight study of synaptic plasticity in adult rat vestibular maculas. Acta Otolaryngol. Suppl. (Stockh.) 516:1-14, 1994.

Ross MD. Changes in ribbon synapses and rough endoplasmic reticulum of rat utricular macular hair cells in weightlessness. Acta Otolaryngol. (Stockh.) 120:490-499, 2000.

Rossi ML, Valli P, Casella C. Post-synaptic potentials recorded from afferent nerve fibres of the posterior semicircular canal in the frog. Brain Res. 135:67-75, 1977.

Salvi RJ, Chen L, Trautwein P, Powers N, Shero M. Hair cell regeneration and recovery of function in the avian auditory system. Scand. Audiol. Suppl 27:7-14, 1998.

Salvi RJ, SAunders SS, Hashino E, Chen L. Discharge patterns of chicken cochlear ganglion neurons following kanamycininduced hair cell loss and regeneration. J. Comp. Physiol. A 174:351-369, 1994.

Santos-SAcchi J. Voltage-dependent ionic conductances of type I spiral ganglion cells from the guinea pig inner ear. J. Neurosci. 13:3599-3611, 1993.
Schessel DA, Ginzberg R, Highstein SM. Morphophysiology of synaptic transmission between type I hair cells and vestibular primary afferents. An intracellular study employing horseradish peroxidase in the lizard, Calotes versicolor. Brain Res. 544:1-16, 1991.

Si X, Angelaki D, Dickman JD. Response properties of pigeon otolith afferents to linear acceleration. Exp. Brain Res. 117:242-250, 1997.

SIEgEL JH. Spontaneous synaptic potentials from afferents terminals in the guinea pig cochlea. Hear. Res. 59:85-92, 1992.

Siegel JH, Dallos P. Spike activity recorded from the organ of Corti. Hear. Res. 22:245-248, 1986.

Sweet H. Head tilt. Mouse News Lett. 63:19-21, 1980.

Tomko DL, Peterka RJ, Schor RH. Responses to head tilt in cat eighth nerve afferents. Exp. Brain Res. 41:216-221, 1981.

Van De Water T, Anniko M, Nordemar H, Wersall J. Embryonic development of the sensory cells in macula utriculae of mouse. In: Portmann M, Aran J-M (eds) Inner Ear Biology, vol. 68. Paris, INSERM, pp. 25-35, 1977.

Walsh BT, Miller JB, GaCeK RR, Kiang NYS. Spontaneous activity in the eighth cranial nerve of the cat. Int. J. Neurosci. 3:221-236, 1972.

Xue B, Skala K, Jones TA, Hay M. Diminished baroreflex control of heart rate responses in otoconia-deficient C57BL/6JEi head tilt mice. Am. J. Physiol. Heart Circ. Physiol. 287:H741-H747, 2004.

YANG A, Hullar TE. Relationship of semicircular canal size to vestibular-nerve afferent sensitivity in mammals. J. Neurophysiol. 98:3197-3205, 2007.

Yao W, Hu R, Jones TA, Hoffman LF. The topographic distribution of calretinin-positive calyces is independent of natural stimulation. Association for Research in Otolaryngology, 30, 2007.

Yates BJ, Miller AD. Physiological evidence that the vestibular system participates in autonomic and respiratory control. J. Vestib. Res. 8:17-25, 1998. 